\title{
Role of the External Auditor in Maximizing Budget Revenues Jordan as a Case Study
}

\author{
Ali Mustafa Magablih \\ Irbid National University - Jordan \\ E-mail: Alimagablih@yahoo.com
}

Received: Jan. 15, 2020 Accepted: Feb. 5, 2020 Online published: Feb. 17, 2020

doi:10.5296/jpag.v10i1.16491ＵRL: https://doi.org/10.5296/jpag.v10i1.16491

\begin{abstract}
External audit is an important factor in maximizing, collecting and increasing the efficiency of the financial departments with regards to controlling the budget revenues and making them smoother and also in the production of accurate and credible tax data and thus a real and fair taxation that achieves the objectives of different parties. External audit works on increasing and promoting the voluntary tax compliance, detecting and deterring cases of tax evasion, controlling the tax collection process almost completely, reducing the efforts of the tax departments through relying on the tax disclosure which would be provided by the taxpayer after an effective audit process; such a process contributes significantly to the prevention of intentional and unintentional cases of tax evasion resulting from fraud and error in both the tax data provided and the financial data on which data was prepared. This subject was strengthened by a field study based on a questionnaire to test the research hypotheses and reach to a set of findings and recommendations, most important of which is that the external audit has a positive role in improving tax collection through the adaptation of the financial departments on the tax disclosure prepared and approved by the auditor and ensuring the existence of a previous process in this regard that would reduce tax collection costs, contributes to the transition from a comprehensive data auditing to selective auditing and helps to eliminate past tax accumulations.
\end{abstract}

Keywords: external auditor, maximizing, budget, revenues

\section{Contribution of the Study}

1- This topic coexists in practical life, a study on the tax situation in Jordan

2- The importance of this research stems from the results of their presentation Jordan

3- Future scholars will benefit from this scholar in this field, researchers and those interested in the topic of the role 
The tax statements approved by the external auditor in the tax assignment

\section{Introduction}

Tax reform in Jordan is one of the most important targets to which the Ministry of Finance seeks; this reform is centered on a number of points, most important of which is reducing the tax accumulations, reaching to a good relationship with taxpayers and determining the tax fairly. There is no doubt that estimating the profits under the tax is one of the most complicated aspects of the tax work however reaching to a real estimation for the taxation is considered a necessary condition for the benefit of both the taxpayer and the tax administration. To achieve this goal, the modern legislations have given the external auditor the responsibility of preparing and approving the tax statement so that it would benefit him in the process of taxation. With regards to the real profit income tax and its mechanisms, we find that the taxpayer is obliged to provide a tax statement within legal periods that show the outcome of business during the year of imposing the taxes followed by confirming the validity of the tax statement data with the help of books, statutory records and related documents to determine the tax profit that differs from the accounting profit. Furthermore, the financial departments may also decide not to fully introduce the tax data as the basis for estimating taxable incomes .

\section{Details Experimental}

\subsection{Problem}

The process of following up the work of the financial departments in the previous period shows poor performance and accumulation of tax work. This led to reconsidering the tax legislation for involving the external auditor in the process of determining the tax profit; interested people in this case believe that the auditor was unable to provide a clear contribution in this process; the financial departments ignore the auditors' reports and their audited and sealed documents and they also re-estimate taxes based on the income estimates and such estimation is sometimes random.

The problem of the research lies in the following questions:

- Does the external auditor contribute to the process of maximizing the budget revenues?

- To what extent do the financial departments rely on the tax disclosure approved by the external auditor in order to maximize the budget revenues?

- To what extent does the adoption on the tax disclosure by the financial departments contribute to maximizing the budget revenues?

\subsection{Objectives}

1. identifying the role of the external auditor in maximizing the revenues

2. determining the confidence of the financial departments in the tax data provided by the external auditor

3. Verifying the extent to which tax data contribute to maximizing revenues 
4. Presenting proper recommendations for improving the submission of tax disclosures in Jordan

\subsection{Hypotheses}

Hypothesis I: The external auditor contributes effectively to the process of maximizing revenues for the budget and holding the legal responsibility.

Hypothesis II: The financial departments rely on the external auditor's approved tax disclosure in the process of maximizing revenues.

Hypothesis III: the financial departments' reliance on the audited tax disclosure contributes to the process of maximizing revenues.

\subsection{Methodology}

This research adopted the descriptive analytical approach through scientific books, legislations and statistics as well as a field study to study the role of the external auditor in maximizing revenues for the budget in Jordan, draw conclusions and make recommendations that contribute to the development of the process of maximizing revenues and raising the performance efficiency.

\section{Previous Studies}

According to the researcher's knowledge, there are no previous studies that addressed the title of the research directly. The previous studies related to the subject were highlighted.

- Mohammed Matar's study entitled with "the role of the external auditor in reducing the effects of the creative accounting on the reliability of the financial returns issued by the Jordanian joint stock companies. The study aimed to identify the methods of the creative accounting used and their impact on the reliability of the accounting data, indicate the motivations of the management for using the creative accounting methods, and to identify the role played by the auditors of these companies in reducing non-creative procedures of accounting used by the boards of directors of the Jordanian joint stock companies with regards to the audited financial returns.

- (Al-Husseini, 2007) entitled with: "the extent of dependence on the accounting information in estimating the income tax of the Palestinian companies. The study examined the extent of relying on the accounting information in estimating tax in the joint companies in the Gaza Strip. The study aimed to identify whether the joint stock company uses accounting systems and identify the qualitative characteristics of the accounting information produced by such systems. The study also aimed to find out whether the Income Tax Department examines the control methods of the accounting programs and their impact on the assessment process in addition to the impact of regulating the accounting profession on the assessment process. The study also aimed to figure out the most frequently used method of estimation by the Income Tax Dept. on the joint companies. The study concluded many results, most important of which is that the joint stock companies have good elements for the accounting system and that they use the disclosure methods very well. 
- (Abdul Ghafoor, 2008), "the relationship between the taxpayer and the tax administration and its impact on collection and taxation". The study aimed to explore the relationship between the taxpayer and the tax administration and its impact on collection and taxation as well as identify the methods of improving such relationship and its effects. The study concluded many results, including: there are factors that positively affect taxation as well as other factors that negatively affect it. As for the factors that have a positive impact, they included: the estimator's rejection of the social pressures (connections), fairness of the taxpayer through the means stipulated in the law, in addition to the law's regulation of the relationship between the taxpayer and the tax administration through the incentives, penalties and fines stipulated. As for the factors that negatively affected taxation, they included: lack of conforming to the taxpayers' rules of justice in the Palestinian income tax and the income tax commissioner's low awareness of his responsibilities.

- (Qahmoush, 2008), "the role of the tax audit in improving the quality of the tax statements." The study aimed to explore the relationship between the tax audit and its role in developing the quality of the tax statements; the tax audit is an important factor in the tax system since it controls it fairly. The quality of the statement is based on the validity and accuracy of the information provided by the taxpayer. The tax audit strategy increases and enhances the voluntary tax compliance and detects and deters non-compliance cases. As for highlighting the development of the tax audit system compared to the taxpayers' statements and the information and accounts they provide and confirming that it is targeted and comprehensive to an adequate percentage of taxpayers, it is considered important since it works on detecting the irregularities committed in order to get them to declare the full and correct information about the income they receive. This was tested throughout a corrective study of the results of the tax audit in addition to questionnaires used to support the answers to the hypotheses of the study. The study concluded that the tax audit had a positive role in improving the quality of the tax permit since the tax audit program as well as its scientific and practical qualifications and its accurate operations encourage taxpayers to announce correct and accurate returns about the taxes, which will eventually lead to increasing the tax revenue.

- (Mescall, 2012), "Corporate Tax Compliance: The Role of Internal and External Preparers". The study aimed to examine the tax reporting strategies to understand how companies manage this difficult task, and the impact of the tax return preparers regarding the tax status of companies and specifically whether the kind of the preparers (external or internal auditor or the chartered not auditing accountant of the company) is related to the chartered tax avoidance through creative accounting methods that legally reduce the tax burdens. By applying the questionnaires to the tax executives and with the use of the data of the U.S. Tax Dept. on those who signed the company's tax return, it was concluded that the preparers of the kind "internal auditors" and "chartered accountants-not auditors" showed a greater avoidance of taxes than the preparers of the kind "external auditors" of the company. The study also showed that only $36 \%$ of the tax executives use external resources in planning for their job and for the decisions related to taxes to which the US economy companies are committed. The study showed that using the company's external auditor for such job was rare. 


\section{Definition of External Audit}

2020, Vol. 10, No. 1

The most comprehensive definition of auditing is that provided by the American Accounting Association: Auditing is an organized and systematic process for gathering evidence and clues regarding the assertions about the economic actions and events and evaluating them objectively to ascertain the degree of compatibility between these assertions and standards and deliver the results to the interested users.

\section{Overall Objectives of the External Auditor}

According to the international standards, the objectives of the auditor include:

A. Obtaining a reasonable assurance as to whether the overall financial data are free from errors whether due to fraud or error; the auditor may express his opinion on whether the financial statements are prepared in terms of all the core aspects according to the framework of preparing the financial statements.

B. Reporting on the financial statements as required by the international auditing standards, in accordance with the results obtained by the auditor in all substantial respects according to the framework of the preparation of the financial statements.

\section{Objective of External Audit}

According to the international standards, the objective of the audit process is:

Enhancing the degree of the target users' confidence in the financial data through the process where the auditor expresses his opinion on whether the financial statements are prepared in terms of all the significant respects in accordance with the framework of preparing the financial reports.

Responsibility for the financial statements:

While the auditor is responsible for the formation of his professional opinion on the financial statements, the responsibility for the preparation and presentation of the financial statements is the duty of the management of the business. According to the framework of preparing reports, the financial statements are the responsibility of the management of the business along with supervisors. Auditing the financial statements does not absolve the administration of its responsibilities for submitting the self-assessment report in Jordan, which is done by the auditor in order to prepare the tax disclosure of the taxpayer in accordance with the provisions of the income law and its amendments, which required from taxpayers to prepare their own disclosures from a certified chartered accountant other than the employees in the Ministry of Finance.

\section{The External Auditor and the preparation of the tax disclosure of the real profit income} $\operatorname{tax}$

Taxpayers can assign the task of preparing the tax statement to the external auditor of the company, which is included in the tax services provided to the administration. As for the preparation of the tax statement by the tax auditors to be provided to the tax department, it 
lies at the core of the job of the external auditor and thus it does not pose any threat to his life.; on the contrary, if the auditor is the one who prepares the tax statement, this provides a guarantee to the tax departments that this statement shows the profits of the project according to the required instructions without deviation. Taking this role by the auditors would provide an additional income to the audit facilities allowing them to deepen their social and economic role. Furthermore, the auditor conducts administrative and financial services (IFAC), which are included in the Handbook of the Professional Conduct issued by the International Federation of Accountants, to the clients at lower costs and shorter time.

However, the tax reputation of the external auditor appointed by the general authority of shareholders plays a role in his appointment by the Department as a preparation for the tax statement. Due to the fact that the Department has the freedom to choose the agency with which it contracts, it may resort to a legal accountant different from the external auditor appointed by the general authority of shareholders according to the management considerations and recommendations of the audit committee.

It has been pointed out in the Ethics code of the Professional Accountants of the International Federation of Accountants (IFAC) that providing such service to the Department does not constitute a threat to the independence if the management (IFAC) is responsible for the tax data, including any significant estimates that have been undertaken; however, the preparation of the current or deferred tax liabilities accounts for the purposes of preparing accounting entries that will be audited later in the audit process may pose a risk of subjective auditing. The auditor should apply preventive measures such as the use of professionals other than the members of the audit team for providing services. In cases where the service should be provided by a member of the audit team, there is a need for a partner or a senior employee with appropriate experience who is not a member of the tax audit team. Another possibility is getting a consultation on services from an external tax expert.

\section{Credibility of the real profit tax statement}

Credibility is defined as the ability to adopt accounting and financial information by its users with the least possible fear. This is achieved by the availability of honest representation, verifiability and neutrality. The Accounting Standards Committee considers the information credibility complementary to the compatibility characteristic. For information to be useful, it must be reliable, dependable and credible if they are free from significant errors and bias. Credibility is divided into two parts related to the information taken from the financial statements of the establishment and a part related to the correctness of the preparation process of the tax statement submitted. The external auditor provides credibility to both parts.

\section{The regulatory authorities on the tax statement for the real profit tax}

The process of taxation is limited to three people: one is responsible for preparing the tax statement based on the financial statements approved by the external auditor which is later certified by a chartered accountant who may be himself the external auditor. Finally, after the submission of the statement, the income estimator checks both of the statement and the establishment again to be sure of the validity of the process. 


\section{MlMacrothink}

Journal of Public Administration and Governance

ISSN 2161-7104

2020, Vol. 10, No. 1

The responsibility of the chartered accountant that is related to the tax return of the real profits tax

The responsibility is defined as: "demanding that the individual holds the consequences of his unlawful actions; actions are unlawful if they are contrary to a legitimate or chartered duty, especially if they cause harm to others, whether by mistake or deliberately. They hold people the consequences of their actions. The accountant adopting the tax return is responsible for several tasks related to the adoption of the tax return. The rules of the code of ethics of accountants regulated the tax practice where the special section issued by the International Federation of Chartered Accountants indicated that the chartered accountant is authorized to provide the best status to the client or the employer within the professional competence. This is done provided that this is not at the expense of honesty, objectivity and contradiction with the provisions of the law. The accountant must also confirm that the tax return is prepared on the basis of the information provided by the taxpayer. Article 5 of section 5 indicated that the professional accountant who performs tax services must be qualified to perform them for the benefit of the client, provided that the service is performed efficiently without prejudice to integrity and objectivity and being consistent with the law. The accountant must also make it clear to the client that the responsibility for the contents of the tax return rests primarily on the client in the first place. The professional accountant must guarantee that the tax return is accurately prepared in light of the executive instructions based on the information provided by the client; the auditor should study and check the restrictions and documents provided to him by the taxpayer. An independent report on the audit certificate show its audit results of these restrictions, documents and the places of flaws if any. The auditor then prepares a report in which he states his opinon clearly with regards to the validity or the invalidity of the results shown by the taxpayer's restrictions. This report or certificate is presented with the tax return of the real profits tax. It is possible to follow up the chartered accountants who proved to have adopted data or submitted reports or certificates contrary to the truth in a way that is contrary to the accounting rules known for the purpose of the tax evasion. This is done by a decision of the Minister of Finance for which the financial departments must prepare reports of the irregularities referred to and then submit them to the Ministry of Finance after the decision of the appeal committee unless it is discussed before the committee reconsidering the auditor in case he is entrusted with preparing the tax return with the following procedures:

1. Evaluating the internal control system and conducting the appropriate tests for it in order to assess its efficiency to achieve the taxpayers' compliance of the tax laws.

2. Drawing the attention of taxpayers with regards to any defect in the internal control system with regard to the qualitative taxes and the fees to which the taxpayer is responsible.

3. Preparing the audit procedures based on sample testing dedicated to the elements of the financial returns to cover the taxpayer's obligations of various qualitative taxes.

4. Obtaining a letter of representation from the taxpayer in which he confirms his commitment to the tax laws. 
5. Informing the audit committee or the management in writing or disclosure in case of any violations of the tax laws.

6. The need that the return contain clear items on the commitment of the taxpayers with the tax laws

7. Requesting the taxpayer to return tax-unacceptable expenses to taxable profits.

8. Carrying out specific auditing procedures for the tax tables in case they existed.

9. Carrying out audit procedures to ensure the adequacy of the tax allowances incurred by the taxpayer.

According to the law, the external auditor preparing the tax return must ensure the presence of an external audit process and he must attach the audit report with the tax return. He must also pay adequate care and confirm that the tax return complies with the tax laws and regulations and that the auditor must not approve any tax return that:

A- Contains false or misleading data.

B- Contains data or information prepared with neglect or without a real knowledge.

C- Deletes or hides required information and this deletion or concealment misleads the tax departments.

The important role played by the tax legislations for the chartered accountant preparing the tax return made him represent the conscience of the society; therefore, his silence about irregularities or tax evasion or his deliberate participation in it exposes him to the loss of the moral status he enjoys. It also leads to the society's disappointment as a result of the transmission of what should be a protection and a control tool to a tool of embezzlement and manipulation. The negative current and future effects on economy are not secret from the public. Furthermore, the provision of the tax return preparation service is also considered a part of the profession of the chartered accountant; therefore, the professional organization that controls this profession can question the associated chartered accountant for his abuse of this profession by committing acts that violate the ethics and dignity of the profession, such as the provision of tax services insufficiently or providing false tax returns. The chartered accountant must not act in a manner that damages his professional reputation in all the services he provides to his client, including the submission of the tax return. All jobs, including auditing have professional organizations that determine the ethical rules and ethics and duties of the professional conduct of the members of the profession. Accordingly, the auditor has a professional responsibility as a result of violating the established rules related to the preparation and adoption of the tax return by the official authorities or the Association of Chartered Accountants.

\section{Population and Sample}

The research population consisted of the income estimators and employees in the financial departments in charge of the tax data in the budget, as well as the Jordanian legal accountants in Jordan. The research sample consisted of all the categories of the external auditors and 
income users in Jordan. 80 questionnaires were distributed to the external auditors and 80 other questionnaires were distributed to the tax estimators and budget officials; 160 distributed questionnaires were 143 recovered.

\section{Statistical Methods}

The fifth Likert scale consisting of five degrees was adopted in order to determine the degree of consistency of the sample items to each question in the questionnaire and convert those to quantitative data; the mean and standard deviation were also used.

\section{Description of the characteristics of the study sample}

Table A shows the distribution of the sample members according to the demographic variables.

Table A. Distribution of the sample members according to the demographic variables

\begin{tabular}{|c|c|c|c|}
\hline Variable & Classification & frequency & percentage \\
\hline \multirow{5}{*}{ Age } & under 30 years & 33 & 23.1 \\
\hline & $30-40$ years & 82 & 57.3 \\
\hline & $41-50$ years & 20 & 14.0 \\
\hline & Over 50 years & 8 & 5.6 \\
\hline & Total & 143 & 100.0 \\
\hline \multirow{6}{*}{ qualification } & Diploma & 22 & 15.3 \\
\hline & Bachelor & 99 & 69,2 \\
\hline & Master & 15 & 10,4 \\
\hline & Ph.D. & 7 & 5,1 \\
\hline & Other & 00 & 0,0 \\
\hline & Total & 143 & 100.0 \\
\hline \multirow{2}{*}{$\begin{array}{l}\text { Number of years } \\
\text { experience }\end{array}$} & less than 5 years & 23 & 16,1 \\
\hline & 5- less than 10 years & 35 & 24,4 \\
\hline
\end{tabular}




\begin{tabular}{|c|c|c|c|}
\hline & 10-less than 15 years & 75 & 52,5 \\
\hline & Over 15 years & 10 & 7,0 \\
\hline & Total & 143 & 100.0 \\
\hline & Tax estimater & 40 & 30 \\
\hline & External Auditor & 93 & 70 \\
\hline & Total & 143 & 100.0 \\
\hline \multirow{5}{*}{ Specialization } & Accounting & 108 & 75,5 \\
\hline & Business Management & 35 & 24.5 \\
\hline & Financial and banking sciences & $\mathbf{0}$ & 000 \\
\hline & Other & $\mathbf{0}$ & 000 \\
\hline & Total & 143 & 100.0 \\
\hline
\end{tabular}

\section{First: Age}

The previous table shows that the majority of the study sample fall in the age group of 30-40 years old by $57.3 \%$, those less than $30 \%(23.1 \%)$, those whose ages range $41-51$ (14\%), and those above $50(5.6 \%)$. Since the highest category represents those whose ages fall between 30-40 the youth, there appeared an interest in employing the youth in the field of accounting at companies.

\section{Second: Scientific qualification}

The table shows that the majority of the members of the study sample hold BA by $(69.4 \%)$, diploma (15.3\%), MA (10.3\%) and $\mathrm{Ph} . \mathrm{D}(5.1 \%)$. This indicates an interest in employing qualified people in the field of accounting in the joint stock companies.

\section{Third: Number of years of experience}

The study table shows the employees' level of experience. The highest was 10-15 year olds (52.5\%), 5-10 years (24.4\%), less than 5 years (16.1\%), and more than 15 years $(7.0 \%)$. We conclude that the joint stock companies maintain highly experienced employees, which enhances the study reliability.

\section{Fourth: Job Title}

The previous table shows that the largest sample was for the external auditors. This 
percentage indicates that respondents are closely related to the subject of the study, which enhances the study reliability and the results that can be achieved.

\section{Fifth: Scientific specialization}

The previous table shows that the vast majority of the study sample was those who studied accounting for 75.5 percent and business management by $(24.5 \%)$. These ratios indicate that respondents were closely related to the subject of the study, which targeted this group. This enhances the credibility and reliability of the study as well as the results that can be reached.

\section{Analysis and Discussion of the Study Results}

Table 1. means and standard deviations of the items of hypothesis I

\begin{tabular}{|c|c|c|c|c|c|}
\hline Rank & No. & Item & mean & $\begin{array}{l}\text { standard } \\
\text { deviation }\end{array}$ & $\begin{array}{l}\text { relative } \\
\text { importance }\end{array}$ \\
\hline 1 & 4 & $\begin{array}{l}\text { I think it is possible to completely } \\
\text { depend on the work of the external } \\
\text { auditor in the process of the taxation } \\
\text { assessment process }\end{array}$ & 4.11 & 1.16 & High \\
\hline 2 & 3 & $\begin{array}{l}\text { The job of the external auditor of } \\
\text { dealing with all the tax data supports the } \\
\text { taxation assessment process and } \\
\text { increases the credibility }\end{array}$ & 4.09 & 1.03 & High \\
\hline 3 & 2 & $\begin{array}{l}\text { Forcing the same external auditor in } \\
\text { adopting the tax statement increases the } \\
\text { effectiveness of the taxation assessment } \\
\text { process }\end{array}$ & 4.01 & 1.06 & High \\
\hline 4 & 5 & $\begin{array}{l}\text { The penalties are sufficient to deter the } \\
\text { external auditors from covering up tax } \\
\text { irregularities }\end{array}$ & 3.63 & 1.2 & Medium \\
\hline 5 & 1 & $\begin{array}{l}\text { The external auditor has a sufficient } \\
\text { experience with regards to taxes }\end{array}$ & 2.97 & 1.17 & Medium \\
\hline 6 & 6 & $\begin{array}{l}\text { There is a direct relationship between } \\
\text { the experience of the external auditor in } \\
\text { laws and the occurrence of a sufficient } \\
\text { external audit }\end{array}$ & 2.9 & 1.46 & Medium \\
\hline
\end{tabular}




\begin{tabular}{|l|l|l|l|l|l|}
\hline 7 & 8 & $\begin{array}{l}\text { There are no matters relating to tax } \\
\text { issues that cannot be detected by the } \\
\text { auditor }\end{array}$ & 2.78 & 1.44 & Medium \\
\hline 8 & 7 & $\begin{array}{l}\text { The external auditor has sufficient } \\
\text { experience regarding taxes }\end{array}$ & 2.55 & 1.3 & Medium \\
\hline \multicolumn{2}{|l|}{ total average } & 3.38 & 0.606 & Medium \\
\hline
\end{tabular}

Table (1) shows that the means of item 4 were (4.11) by a high degree. However, in the final rank was item (7) with a mean of (2.55) by a medium degree. The mean of the total field was (3.38) by a medium degree.

\section{Hypothesis I}

Null-hypothesis: The external auditor does not effectively contribute to maximizing the revenues of the budget and holding the legal responsibility entailed.

Alternative hypothesis: The external auditor contributes effectively to maximizing the revenues for the budget and holding the legal responsibility entailed.

It is evident that the value of the mean for the questions combined higher than the mean of the scale which is considered high and it exceeds the approved ratio. This confirms no dispersion in the One Sample T-Test among the respondents ' answers. To confirm the previous analysis, a test of the statistical significance in the difference between the mean and the mean of the scale tool used. The alternative hypothesis stating "The external auditor contributes effectively to maximizing the revenues for the balance or holing the legal responsibility" was approved.

Testing the first hypothesis

\begin{tabular}{|l|l|l|l|l|l|}
\hline Hypothesis & mean & $\begin{array}{l}\text { variation } \\
\text { rate \% }\end{array}$ & $\begin{array}{l}\mathbf{T} \\
\text { calculated }\end{array}$ & argumentative & Result \\
\hline first & 3.38 & 22.14 & 12.11 & 2.009 & $\begin{array}{l}\text { rejecting the null } \\
\text { hypothesis }\end{array}$ \\
\hline
\end{tabular}

The null hypothesis: The external auditor does not contribute effectively in the tax assignment process and its consequent chartered liability. The alternative hypothesis: the external auditor contributes effectively to the tax assignment process and its chartered responsibility.

The null hypothesis: The external auditor does not contribute effectively in the process of maximizing the budget's revenues and its consequent chartered liability. The alternative hypothesis: the external auditor contributes effectively to the process of maximizing the budget's revenues and its chartered responsibility. 
From the above table, we note that the mean of the total questions was 3.38, which is higher than the mean of the measurement tool of 3 by $82.77 \%$, which is higher than the approved percent of $60 \%$ by a variance factor of $22.14 \%$ that is much less than the adopted percent of $50 \%$. This confirms that there is no significant dispersion for the One Sample T-test among the respondents' answers. To confirm the previous analysis, the test of the presence of a statistical significance was used between the mean of 4.1319 and the mean of the measurement tool of 3 where the t-scale was 2.009 at the calculated t level of 12.11 of the sample and the mean of the measurement tool was 3 . In light of the above analysis of the data of the hypothesis, the null hypothesis is rejected and the alternative hypothesis is accepted.

Table 2. means and standard deviations of the items of hypothesis II

\begin{tabular}{|c|c|c|c|c|c|}
\hline Rank & No. & Item & mean & $\begin{array}{l}\text { standard } \\
\text { deviation }\end{array}$ & $\begin{array}{l}\text { relative } \\
\text { importance }\end{array}$ \\
\hline 1 & 3 & $\begin{array}{l}\text { The taxation assessment process applied in } \\
\text { the financial departments facilitates dealing } \\
\text { with the tax data of those subject to } \\
\text { taxation leading to detecting errors and } \\
\text { fraud }\end{array}$ & 4.63 & 0.811 & High \\
\hline 2 & 4 & $\begin{array}{l}\text { The tax administration provides the } \\
\text { necessary tools and means for submitting } \\
\text { the tax statement in all its stages }\end{array}$ & 4.18 & 1.09 & High \\
\hline 3 & 6 & $\begin{array}{l}\text { Among the objectives of the tax } \\
\text { administration is depending on the audited } \\
\text { tax data completely }\end{array}$ & 4.03 & 1 & High \\
\hline 4 & 5 & $\begin{array}{l}\text { The unsealed tax statement is adopted in } \\
\text { the taxation assessment process }\end{array}$ & 3.8 & 1.11 & High \\
\hline 5 & 9 & $\begin{array}{l}\text { The currently applied tax statement has } \\
\text { sufficient information that enables } \\
\text { calculating taxes }\end{array}$ & 3.76 & 1.16 & High \\
\hline 6 & 8 & $\begin{array}{l}\text { The tax statement is the basis in } \\
\text { determining the tax to be deducted. }\end{array}$ & 3.29 & 1.36 & Medium \\
\hline 7 & 2 & $\begin{array}{l}\text { The assessment number found in the tax } \\
\text { statement is fully adopted }\end{array}$ & 3.09 & 1.42 & Medium \\
\hline
\end{tabular}




\begin{tabular}{|l|l|l|l|l|l|}
\hline 8 & 7 & $\begin{array}{l}\text { The tax deducted does not exceed that } \\
\text { mentioned in the statement in most cases }\end{array}$ & 3.09 & 1.32 & Medium \\
\hline 9 & $1 \quad \begin{array}{l}\text { There is a full obligation of the legislative } \\
\text { authorities to control the income based on } \\
\text { the tax statement }\end{array}$ & 2.78 & 1.29 & Medium \\
\hline \multicolumn{2}{|l|}{ total average } & 3.62 & .597 & Medium \\
\hline
\end{tabular}

Table (2) shows that the means of item 3 was (4.63) by a high degree. Item 1 came in the final rank by a mean of (2.78) by a medium degree. The mean for the field as a whole was (3.62) by a medium degree.

Testing the second hypothesis

\begin{tabular}{|l|l|l|l|l|l|}
\hline hypothesis & mean & variation rate \% & $\begin{array}{l}\text { T } \\
\text { calculated }\end{array}$ & argumentative & Result \\
\hline second & 3.62 & 57.4 & -1.16 & 2.009 & $\begin{array}{l}\text { Accepting the null } \\
\text { hypothesis }\end{array}$ \\
\hline
\end{tabular}

Null hypothesis: the financial departments do not rely on the tax disclosure approved by the external auditor in the process of maximizing the revenues.

Alternative hypothesis: the financial departments do not rely on the adopted tax return of the external auditor in the process of maximizing revenues.

The table shows that the sample respondents do not approve most of the items since the mean of all the questions was 3.62. To verify that the mean indicated by the respondents for these differences is significantly less than the mean of the measurement tool being not coincidental, a test was used to examine the extent of a statistical significance in the difference between the mean and the mean of the sample T-test of -1.16 , which is less than the value of $t$ of the measuring tool (3). Thus, the table shows that there is no significance in the difference between the mean of the sample answers and the mean of the measurement tool. This indicates that there is a significant difference between the mean of the sample answers and the mean of the measurement tool, so we accept the null hypothesis. 
Table 3. means and standard deviations of the items of hypothesis III

\begin{tabular}{|c|c|c|c|c|c|}
\hline Rank & No. & item & mean & $\begin{array}{l}\text { standard } \\
\text { deviation }\end{array}$ & $\begin{array}{l}\text { relative } \\
\text { importance }\end{array}$ \\
\hline 1 & 4 & $\begin{array}{l}\text { The requirement to approve the tax } \\
\text { statement from a chartered accountant } \\
\text { gives it more confidence }\end{array}$ & 4.28 & 0.907 & High \\
\hline 2 & 1 & $\begin{array}{l}\text { The penalties and fines applied to oblige } \\
\text { those charged with the approval of the tax } \\
\text { statement from a chartered accountant are } \\
\text { sufficient }\end{array}$ & 4.01 & 1.22 & High \\
\hline 3 & 5 & $\begin{array}{l}\text { The penalties are sufficient to deter the } \\
\text { chartered accountants from adopting } \\
\text { incorrect tax data }\end{array}$ & 4.01 & 1.09 & High \\
\hline 4 & 6 & $\begin{array}{l}\text { The employees of the financial } \\
\text { departments do not have sufficient } \\
\text { expertise to audit the tax matters }\end{array}$ & 3.92 & 1.13 & High \\
\hline 5 & 2 & $\begin{array}{l}\text { There is no need for a tax review by the } \\
\text { tax departments }\end{array}$ & 3.83 & 1.13 & High \\
\hline 6 & 8 & $\begin{array}{l}\text { The tax review done by the income } \\
\text { assessor is a replay of what the external } \\
\text { auditor has done }\end{array}$ & 3.64 & 1.1 & Medium \\
\hline 7 & 3 & $\begin{array}{l}\text { The tax review done by the tax } \\
\text { departments do not affect the tax } \\
\text { obligation of the taxpayers }\end{array}$ & 3.59 & 1.18 & Medium \\
\hline 8 & 7 & $\begin{array}{l}\text { in case both the auditor and the sealed tax } \\
\text { statement were adopted, the tax } \\
\text { accumulation file will be terminated }\end{array}$ & 3.23 & 1.18 & Medium \\
\hline \multicolumn{3}{|c|}{ total average } & 3.81 & .642 & High \\
\hline
\end{tabular}

Table 3 shows that the means of the items of the field ranged (3.23-4.28) with item 4 as the highest by a mean of (4.28) by a high degree. Item 7 was in the final rank by a mean of (3.23) with a medium degree and the mean for the total field was (3.81) by a high degree.

\section{Hypothesis III}




\section{Ml Macrothink}

Journal of Public Administration and Governance

ISSN 2161-7104

2020, Vol. 10, No. 1

Null-hypothesis: the financial departments' reliance on the audited tax disclosure contributes to maximizing revenues

Alternative hypothesis: The financial departments' reliance on the audited tax disclosure contributes to maximizing revenues

The value of the mean of the questions which is higher than the mean of the measurement tool which is higher than the approved ratio this indicates a compatibility in the responses of the participants in the One Sample T-Test. Based on the analysis of the data related to the hypothesis, the null-hypothesis is rejected, and the alternative hypothesis stating: "The financial departments' reliance on the audited tax disclosure contributes to maximizing the budget's revenues" is accepted.

Testing the third hypothesis

\begin{tabular}{|l|l|l|l|l|l|}
\hline hypothesis & Mean & $\begin{array}{l}\text { variation } \\
\text { rate \% }\end{array}$ & $\begin{array}{l}\text { T } \\
\text { calculated }\end{array}$ & Argumentative & Result \\
\hline third & 3.81 & 90.16 & 19.76 & 2.009 & $\begin{array}{l}\text { rejecting the null } \\
\text { hypothesis }\end{array}$ \\
\hline
\end{tabular}

Null hypothesis: The financial departments' reliance on the audited tax return does not contribute to the process of maximizing revenues.

Alternative hypothesis: The financial departments' reliance on the audited tax disclosure contributes to the process of maximizing revenues.

The table shows that the mean of the total questions are much higher than the mean of the measurement tool of 3, which is higher than the approved ratio. This indicates a harmony in the one Sample T-test for the answers of the respondents and a confirmation of a statistical indication of the difference between the mean and the mean of the measurement tool of 3 for all the differences included in the table. This indicates a significance between the mean of the sample answers and the mean of the measurement tool. Based on the above analysis of the data on the hypothesis, the null hypothesis is rejected and the alternative hypothesis is accepted.

\subsection{Conclusions and Recommendations}

First: Results

1. The external auditor effectively contributes to maximizing the budget's revenue as a whole for the benefit of the financial departments and taxpayers.

2. The duties of the external auditor with regards to all the tax data supports the disclosure process and makes it more credible by ensuring congruence between the financial statements and tax data. 


\section{Macrothink}

Journal of Public Administration and Governance ISSN 2161-7104 2020, Vol. 10, No. 1

3. The external auditor can clarify points in the tax law that cause major problems for taxpayers and thus contribute to the improvement of tax revenues in the future.

4. The requirement to adopt the tax statement from a legal accountant gives him greater confidence.

5. Penal sanctions are sufficient to deter legal accountants from adopting incorrect tax data.

6. In case of relying on the auditor's job and the sealed tax statement, the tax accumulation file will be terminated.

Second: Recommendations

1. The need to activate the auditor's job with regards to the adoption of the tax statement and forcing the income estimators to accept the figures contained therein without any increase in most cases.

2. Working on increasing the tax departments' reliance on the tax data adopted by the chartered accountants, as this will encourage them to use the voluntary tax compliance and to report their profits.

3. Working to increase interest in tax data by the tax departments in terms of models, content, ease of filling, understanding and appearance.

4. Working on increasing the effectiveness of the taxation process and searching for ways to reduce its costs to the benefit of the public treasury of the country.

5. Working on increasing the awareness of the legal accountants of the penalties that may be imposed on them if they adopt incorrect tax data, as this may be a deterrent to them more than applying such penaltie.

\section{References}

Abdul, G. H. (2012). The relationship between the taxpayer and the tax administration and its impact on collection and taxation, (Master's Thesis), Al-Najah National University, Palestine, 2012.

Accounting Auditing in accordance with International Standards. (2015). Ahmed Qayed.

Al-Husseini, H. (2011). Accounting Responsibility. journal of Baghdad Faculty of Economics, 28 .

Al-Mahayni, K., Al-Khatib, K., \& Al-Aday. (2011). Tax Accounting. Syria: Damascus University Publications, 2011.

An in-depth study of auditing by: Mohammed Fadl Massad 2018

Boubaker, Z. (2015). Activating the external audit as a tool to improve the quality of financial reports, Shahid Hama Lakhkar Al-Wadi University, 2015. 


\section{Macrothink}

Journal of Public Administration and Governance ISSN 2161-7104 2020, Vol. 10, No. 1

Kenneth, K. P., Lisowsky, D., \& Mescall, (2012). University Avenue, West Waterloo, Corporate Tax Compliance: The Role of Internal and External Preparers, Canada, 2012. https://doi.org/10.2139/ssrn.2152538

Governmental Accounting: 2019 Edition Paperback by Steven M. Bragg.

International Ethics Standards Board for Accountants (IESBA), Handbook. The Code of Ethics for Professional Accountants, www.ethicsboard.org, (USA :New York, International Federation of Accountants (IFAC), 2013.

International Auditing and Assurance Standards Board, Handbook of International Quality Control, Auditing, Review, Other Related Services Pronouncements, Edition Volume II, http://www.ifac.org/,Related Services Pronouncements, Edition Volume II, http://www.ifac.org/, )USA: New York, International Federation of Accountants (IFAC), 2013.

Musameh, M., \& Laqwera, S. (2017). the contribution of the vocational specialization of the External Auditor in improving the quality of the Audit: field study on a sample of external auditors in the state of Biskra. Journal of Economics, 2017.

Qahmoush, S. (2013). The role of the tax accounting in improving the quality of tax data, (Master's Thesis), University of Qasdi, 2013.

Ruba, S. S. A. A. (2016). determinants of the profession market of external audit in Jordan and its impact on the quality of financial reports, Middle East University, 2016.

Tax Saving Strategies and the Mindset needed to take advantage. Paden Squires, 2018.

\section{Copyright Disclaimer}

Copyright for this article is retained by the author(s), with first publication rights granted to the journal.

This is an open-access article distributed under the terms and conditions of the Creative Commons Attribution license (http://creativecommons.org/licenses/by/4.0/). 